\title{
KAJIAN MUTU IKAN CAKALANG (Katsuwonus pelamis, L.) ASAP DARI TEMPAT PENGASAPAN DESA GIRIAN ATAS YANG DIKEMAS VAKUM DAN NON VAKUM SELAMA PENYIMPANAN DINGIN
}

\author{
Gabriella Christy Angela ${ }^{1}$, Feny Mentang ${ }^{2}$, Grace Sanger $^{2}$ \\ 1) Mahasiswa pada Program Studi Teknologi Hasil Perikanan FPIK Unsrat Manado \\ ${ }^{2)}$ Staf pengajar pada Program Studi Teknologi Hasil Perikanan FPIK Unsrat Manado
}

\begin{abstract}
Sub sector of fishery is constitute primary mainstay which source of food and nutrition for Indonesian society. Fish is a source of protein also recognized as "function food" which has significant important for health because it contains unsaturated fatty acid chain length (especially those classified as Omega-3 fatty acid), vitamins, as well as macro minerals. One way of processing and preserving fish is by fogging. Fogging is a way of processing or preservation by utilizing a combination of drying treatment and giving the natural chemical compound from the results combustion of natural fuel. One right way to maintain durable power of cakalang (Katsuwonus pelamis, L.) is by the vacuum packed fish. The main principles of the vacuum packed is expenditure especially air from the product so that extend the self life. And next modified with the cold storage to obtain good results. This research aims to observe the setback chemical quality of cakalang. Fogging for 0 day, 7 day, and 21 st day. Storage temperatures $\left(5^{\circ} \mathrm{C}\right)$ at vacuum and non vacuum packed with testing of the quality water content, $\mathrm{pH}$, Total Plate Count (TPC), Total Volatile Base Nitrogen (TVBN), and Organoleptik. The Method Experiment Explorative which reveal facts based on the exciting problems by hypothesis. Parameter used in this research is testing water content, $\mathrm{pH}, \mathrm{TPC}, \mathrm{TVB}$, and Organoleptik. The results of this research from 5 parameter obtained: The Value of highest water level $(53.95 \%)$, lowest $(20.14 \%)$. The Value of highest $\mathrm{pH}$ (5.9), lowest (5.8). The Value of highest TVB $(43.36 \mathrm{mg} \mathrm{N} / 100 \mathrm{gr})$, lowest $(21.84 \mathrm{mg}$ $\mathrm{N} / 100 \mathrm{gr})$. The Value of highest TPC (TBUD), lowest $(<30)$. The Organoleptic value of flavor $(6.3-8.2)$, appearance (4.3-7.5), aroma (4.3-8.9) and texture (4.9-7.9).
\end{abstract}

Keyword: $\quad$ Skipjack (Katsuwonus pelamis L), Smoke, Study Quality, Chemical, TVB-N, pH, Moisture, TPC, Organoleptik.

Sub sektor perikanan merupakan andalan utama sumber pangan dan gizi bagi masyarakat Indonesia. Ikan merupakan sumber protein, juga diakui sebagai functional food yang mempunyai arti penting bagi kesehatan karena mengandung asam lemak tak jenuh berantai panjang (terutama yang tergolong asam lemak omega-3), vitamin serta makro dan mikro mineral. Salah Satu cara pengolahan dan pengawetan ikan adalah dengan cara pengasapan. Pengasapan merupakan cara pengolahan atau pengawetan dengan memanfaatkan kombinasi perlakuan pengeringan dan pemberian senyawa kimia alami dari hasil pembakaran bahan bakar alami. Salah satu cara yang tepat untuk mempertahankan daya awet ikan cakalang (Katsuwonus pelamis L.) asap yaitu dengan dikemas vakum. Prinsip utama dari pengemasan vakum adalah pengeluaran khususnya 02 dari produk sehingga dapat memperpanjang masa simpan. Selanjutnya dimodifikasi dengan penyimpanan dingin untuk memperoleh hasil yang lebih baik. Penelitian ini bertujuan untuk mengamati kemunduran mutu kimiawi ikan Cakalang asap selama 0 hari, 7 hari, dan 21 hari, penyimpanan pada suhu dingin $\left( \pm 5^{\circ} \mathrm{C}\right)$ yang dikemas vakum dan non vakum dengan pengujian mutu meliputi Kadar air, pH, Total Plate Count (TPC), Total Volatile Base Nitrogen (TVB-N), dan Organoleptik. Metode penelitian yang digunakan adalah metode eksperimen eksploratif yaitu mengungkapkan fakta-fakta berdasarkan permasalahan yang ada melalui hipotesa. Parameter yang digunakan dalam penelitian adalah uji Kadar Air, uji pH, uji TPC, uji TVB-N, dan uji Organoleptik. Hasil penelitian yang diperoleh dari 5 parameter uji, diperoleh nilai kadar air tertinggi $(53,95 \%)$, terendah (20,14\%); nilai $\mathrm{pH}$ tertinggi 5,9, terendah 5,8; nilai TVB tertinggi (45,36mg N/100gr), terendah $(21,84 \mathrm{mg} \mathrm{N} / 100 \mathrm{~g})$; nilai TPC tertinggi (TBUD), terendah $(<30)$; nilai Organoleptik (Rasa) tertinggi $(8,2)$, terendah $(6,3)$; nilai Organoleptik (Kenampakan) tertinggi $(7,5)$, terendah $(4,3)$; Nilai Organoleptik (Bau) tertinggi $(8,9)$, terendah $(4,3)$; nilai Organoleptik (Tekstur) tertinggi $(7,9)$, terendah $(4,9)$.

Kata Kunci: Ikan Cakalang (Katsuwonus pelamis L.), asap, Kajian Mutu, TVB-N, pH, Kadar Air,TPC, Organoleptik. 


\section{PENDAHULUAN}

Subsektor perikanan dan peternakan merupakan andalan utama sumber pangan dan gizi bagi masyarakat Indonesia. Ikan, selain merupakan sumber protein, juga diakui sebagai functional food yang mempunyai arti penting bagi kesehatan karena mengandung asam lemak tidak jenuh berantai panjang (terutama yang tergolong asam lemak omega-3), vitamin, serta makro dan mikro mineral. Ikan merupakan sumber bahan pangan yang bermutu tinggi, karena ikan banyak mengandung protein, lemak, vitamin, dan mineral yang sangat dibutuhkan manusia. Ikan mengandung 18 persen protein terdiri dari asam-asam amino esensial dan non esensial, kandungan lemaknya 1-20 persen yang terdiri atas asam lemak jenuh dan asam lemak tak jenuh.

Salah satu jenis pengolahan yang dapat digunakan untuk menghambat kegiatan zat-zat mikroorganisme adalah pengasapan ikan, selain bertujuan memberikan manfaat untuk mengawetkan ikan, pengolahan ikan dengan cara pengasapan juga memberi aroma yang sedap, warna kecoklatan atau kehitaman, tekstur yang bagus serta cita rasa yang khas dan lezat pada daging ikan yang diolah (Wibowo, 1996). Pengasapan merupakan suatu cara pengolahan atau pengawetan dengan memanfaatkan kombinasi perlakuan pengeringan dan pemberian senyawa kimia dari hasil pembakaran bahan bakar alami (Wibowo, 2000).

Pengasapan dapat didefinisikan sebagai proses penetrasi senyawa volatil pada ikan yang dihasilkan dari pembakaran kayu yang dapat menghasilkan produk dengan rasa dan aroma spesifik umur simpan yang lama karena aktivitas anti bakteri, menghambat aktivitas enzimatis pada ikan sehingga dapat mempengaruhi kualitas ikan asap. Senyawa kimia dari asap kayu umumnya berupa fenol (yang berperan sebagai antioksidan), asam organik, alkohol, karbonil, hidrokarbon dan senyawa nitrogen seperti nitro oksida, aldehid, keton, ester, eter, yang menempel pada permukaan dan selanjutnya menembus ke dalam daging ika. (Isamu, 2012), kontrol suhu sulit dilakukan dan mencemari udara (Swastawati, 2011).

Produksi perikanan Indonesia cukup besar, untuk perikanan tangkap dan budidaya, tahun 2006 sebesar 7.488.708 ton, tahun 2010 meningkat menjadi 10.826 .502 ton (KKP 2011).
Hasil perikanan tersebut pada umumnya dikonsumsi dalam bentuk segar, diekspor dan diolah baik secara modern maupun tradisional. Produksi ikan fufu di Indonesia pada tahun 2007 mencapai 66.970 ton, masih jauh di bawah produksi ikan asin yaitu 473.679 ton (JICA 2009). Produksi ikan fufu di Sulawesi Utara sebesar 31.408 ton (DKP Sulut, 2010), atau $17 \%$ dari produksi total ikan Sulut dan $46,89 \%$ dari total produksi ikan fufu Indonesia.

Ikan Cakalang fufu merupakan ikan asap khas Sulawesi Utara termasuk exotic produk yang semakin digemari dan diminati oleh konsumen baik lokal maupun internasional, sehingga menjadi wisata kuliner atau sebagai souvenir khas Sulawesi Utara. Pengolahan ikan Cakalang asap di Sulawesi Utara umumnya masih dilakukan secara tradisional atau pengolahan dilakukan secara turun temurun. Ikan fufu menjadi awet karena adanya pengurangan kadar air akibat dari proses pemanasan dan adanya senyawa-senyawa kimia di dalam asap seperti golongan fenol yang dapat menghambat pertumbuhan mikroorganisme dan berperan sebagai antioksidan, walaupun begitu pengasapan ikan pada saat ini dilakukan dengan tujuan untuk memberikan warna, tekstur dan flavor yang khas (Bligh et al. 1988; Martinez et al. 2007).

Cara pengolahan yang kurang saniter dan higienis, serta penyimpanan dalam keadaan tidak dilindungi atau dikemas dengan baik pada kondisi tropis, mengakibatkan produk ikan olahan tradisional sangat rentan terhadap kerusakan mikrobiologis. Kerusakan ini dapat menyebabkan pembusukan produk baik oleh bakteri atau jamur yang pathogen maupun oleh racun yang dihasilkan. Pengolahan yang dikombinasikan dengan pemanasan dan kontaminasi dari para pengolah tidak terhindarkan, maka produk ikan asap juga rentan pertumbuhan Staphylococcus aureus. Bahaya lain yang terjadi adalah keracunan akibat pertumbuhan Clostridium Botulinum, bakteri pembentuk spora yang sangat tahan panas, yang menghasilkan racun botulisme (Heruwati, 2002).

Kemunduran mutu ikan disebabkan oleh aksi enzimatis dan bakteri, kedua aksi ini mengurai komponen penyusun jaringan tubuh ikan sehingga menghasilkan perubahan fisik seperti daging ikan menjadi lunak dan perubahan kimia yang menghasilkan senyawa yang mudah menguap dan berbau busuk 
(Hadiwiyoto,1993). Senyawa yang mudah menguap memberi kesan ikan telah menjadi busuk, sehingga senyawa-senyawa ini dipakai sebagai indeks kemunduran mutu ikan asap. Kadar senyawa menguap ini dapat ditentukan secara laboratoris yang disebut dengan penentuan kadar TVB-N (Suwetja, 1993). Penentuan kadar TVB-N merupakan metode uji kesegaran kimiawi atau uji kemunduran yang berkaitan dengan pengujian kadar air dan penentuan $\mathrm{pH}$, semakin besar nilai kadar TVB maka makin tinggi nilai $\mathrm{pH}$-nya.

Salah satu usaha yang dilakukan dalam peningkatan mutu dan nilai ekonomi suatu produk adalah dengan pengemasan yang baik, aman dan efisien (Anonimous, 2007). Pengemasan vakum adalah sistem pengemasan hampa udara dimana tekanannya kurang dari 1 atm dengan cara mengeluarkan udara dari kemasan sehingga memperpanjang umur simpan. Proses pengemasan vakum ini dilakukan dengan cara memasukkan produk ke dalam kemasan plastik yang diikuti dengan pengontrolan udara menggunakan mesin pengemas vakum, kemudian ditutup dan disegel. Dengan ketiadaan udara dalam kemasan, maka kerusakan akibat oksidasi dapat dihilangkan sehingga kesegaran produk yang dikemas akan lebih bertahan 3-5 kali lebih lama daripada produk yang dikemas dengan pengemasan non-vakum (Jay 1996).

\section{METODOLOGI PENELITIAN}

Metode penelitian yang digunakan adalah metode eksperimen eksploratif yaitu mengungkapkan fakta-fakta berdasarkan permasalahan yang ada melalui hipotesa. Menurut Hadi (1970), penelitian eksperimen eksploratif adalah penjelajahan yang bermaksud mencari permasalahan atau pengembangan hipotesa tentang hubungan sebab akibat atau gejala.

\section{Tempat dan Waktu Penelitian}

Sampel Ikan Cakalang (Katsuwonus pelamis L) asap diambil dari Desa Girian Atas. Pengujian mutu ikan dilaksanakan di Laboratorium Pengendalian Mutu Hasil Perikanan dan Penanganan Hasil Perikanan, Fakultas Perikanan dan Ilmu Kelautan Universitas Sam Ratulangi Manado. Penelitian dilaksanakan selama 1 bulan (Juni-Juli 2015).

\section{Alat dan Bahan}

Alat-alat yang digunakan dalam penelitian ini antara lain: lemari pendingin untuk tempat penyimpanan sampel dengan kisaran suhu $4-5^{\circ} \mathrm{C}$, termometer, cool box, timbangan analitik, oven, Erlenmeyer, Magnetic stirrer, tabung reaksi, spatula, pipet steril, beaker glass, gelas ukur, cawan petri, autoclave, laminarflow, incubator, wadah penyimpanan/ piring, pisau, tissue, mortar, $\mathrm{pH}$-meter, beaker glass, gelas ukur, kertas saring whatman no.2, cawan conway, pipet, inkubator, corong kaca, cawan porselen, alat penjepit, desikator, silika gel, oven, dan mikroburet.

Bahan yang digunakan antara lain: Ikan Cakalang, Nutrient Agar (NA), akuades, $\mathrm{NaCl}$ 0,9, larutan TCA (Trikhloroacetic Acid) 7\%, larutan Kalium Karbonat $\left(\mathrm{K}_{2} \mathrm{CO}_{3}\right)$ jenuh, TCA 7,5 \%, Larutan Indikator (methil red dan bromo cresol green), Asam Borat $\left(\mathrm{H}_{3} \mathrm{BO}_{3}\right)$, Asam Klorida $(\mathrm{HCl} 0,02 \mathrm{~N})$, Vaselin, larutan buffer pH 7, akuades, silika gel, Plastik Kris (Size 28 $\mathrm{x} 40 \mathrm{~cm})$.

\section{Perlakuan}

Waktu penelitian diasumsikan dilakukan pada waktu yang sama setiap harinya. Ulangan yang digunakan dalam penelitian adalah sebanyak 2 kali.

Perlakuan(A), waktu penyimpanan dengan suhu $\pm 5^{\circ} \mathrm{C}$ :

$$
\begin{aligned}
& A 1=0 \text { hari } \\
& \text { A2 }=7 \text { hari } \\
& \text { A3 }=21 \text { hari }
\end{aligned}
$$

Perlakuan (B), cara pengemasan:

$\mathrm{B} 1=$ Vakum

$\mathrm{B} 2=$ Non Vakum

\section{Tata Laksana Penelitian}

Tata Laksana Penelitian adalah sebagai berikut:

- Sampel yang digunakan dalam penelitian ini adalah ikan Cakalang asap sebanyak 12 jepit dengan berat rata-rata $2-3 \mathrm{~kg} / \mathrm{jepit}$, dibeli dari beberapa pengolah ikan di Girian Atas Kota Bitung, sampel dimasukan dalam plastik kemudian dimasukan ke dalam wadah Styrofoam yang berisi es, dan dibawa ke Laboratorium Pengendalian Mutu Hasil Perikanan untuk perlakuan selanjutnya.

- Kemudian sampel dibagi menjadi 2 bagian masing-masing dikemas vakum dan non vakum dan disimpan pada suhu dingin $\left( \pm 5^{\circ} \mathrm{C}\right)$ selama 21 hari. 
- Analisa yang dilakukan meliputi Pengujian TPC (Total Plate Count), TVB-N (Total Volatile Base Nitrogen) dengan metode Conway, kadar air menggunakan metode oven, uji $\mathrm{pH}$ dengan menggunakan $\mathrm{pH}$ meter dan organoleptik. Pengujian organoleptik dilakukan pada sampel utuh. Pengujian dilakukan secara bersamaan untuk ke-lima parameter uji.

- Pengujian TPC, TVB-N, pH, kadar air, dan organoleptik sampel dilakukan dengan 2 kali ulangan untuk setiap perlakuan penyimpanan.

\section{Parameter Yang di Uji}

Parameter yang diamati adalah Analisa Kadar Air, pH, Total Volatile Base-Nitrogen (TVB-N), TPC (Total Plate Count).

\section{Analisa Kadar Air}

Menurut Sudarmadji, $d k k$ (1989), Kadar air ditentukan dengan menghitung kehilangan berat dari sampel yang dipanaskan. Prosedurnya adalah sebagai berikut :

- Cawan porselin dan penutupnya dibersihkan kemudian dikeringkan dan dioven pada suhu $105^{\circ} \mathrm{C}-110^{\circ} \mathrm{C}$ selama $1 \mathrm{jam}$, selanjutnya didinginkan dalam desikator selama 30 menit dan ditimbang beratnya (A).

- Sampel ditimbang sebanyak 2 gr dalam cawan porselen yang sudah diketahui beratnya (B). Sampel dalam cawan porselen ini kemudian dikeringkan dalam oven pada suhu $105^{\circ} \mathrm{C}-110^{\circ} \mathrm{C}$ selama $24 \mathrm{jam}$, selanjutnya didinginkan dalam desikator selama 30 menit dan ditimbang (C).

- Penimbangan ini dilakukan berulang-ulang sampai diperoleh berat yang konstan. Persentase kadar air dapat dihitung dengan rumus :

$$
\text { Kadar Air }=\frac{(B-C)}{(B-A)} \times 100 \%
$$

\section{Penentuan Nilai pH}

Menurut Suwetja, dkk. (2007), bahwa penentuan $\mathrm{pH}$ dapat dilakukan dengan menggunakan $\mathrm{pH}$ meter, dengan urutan kerja sebagai berikut:

- Timbang sampel yang telah dirajang kecilkecil sebanyak $10 \mathrm{~g}$ dihomogenkan menggunakan mortar dengan $20 \mathrm{ml}$ akuades selama 1 menit.

- Tuangkan ke dalam beker glass $10 \mathrm{ml}$, kemudian diukur pH-nya dengan menggunakan $\mathrm{pH}$ meter.
- Sebelum pH meter digunakan, harus ditera kepekaan jarum penunjuk dengan larutan buffer $\mathrm{pH} 7$.

- Besarnya pH adalah pembacaan jarum penunjuk $\mathrm{pH}$ setelah jarum skala konstan kedudukannya.

\section{Analisis Nilai TVB-N}

Menurut Suwetja (1992), analisa TVB-

$\mathrm{N}$ adalah sebagai berikut :

- Daging ikan ditimbang sebanyak 5 g dengan menggunakan timbangan analitik, dihaluskan menggunakan mortar kemudian dihomogenkan dengan $10 \mathrm{ml}$ larutan TCA 7,5 $\%$ di dalam mortar sampai sampel homogen. Kemudian sampel di pindahkan ke gelas beaker terus di diamkan selama 30 menit.

- Selama menunggu proses tersebut, permukaan badan cawan Conway beserta tutupnya diolesi dengan vaselin secara merata untuk mencegah keluarnya basa-basa menguap dari dalam cawan tersebut.

- Sampel yang didiamkan tadi disaring dengan kertas whatman (no. 2-3) untuk mendapatkan ekstrak daging.

- selanjutnya $1 \mathrm{ml}$ larutan Asam Borat (H3BO2), dan 2 tetes larutan indikator dipipetkan ke dalam cawan bagian dalam (inner chamber).

- Dipipet $1 \mathrm{ml}$ ekstrak daging ke dalam cawan bagian luar (outer chamber), kemudian cawan ditutup dengan sedikit terbuka.

- Selanjutnya dipipetkan $1 \mathrm{ml}$ larutan Potassium Karbonat Jenuh (K2CO3) ke dalam cawan bagian luar di sisi yang bersebrangan dengan ekstrak daging kemudian ditutup rapat.

- Kemudian diputar-putar beberapa kali supaya larutan ekstraksi daging ikan dan larutan Potassium Karbonat (K2CO3) dapat tercampur.

- Bersamaan dengan pekerjaan di atas, dibuat blanko, di mana sebagai pengganti larutan ekstraksi daging ikan dipakai $1 \mathrm{ml}$ larutan TCA 7,5\%.

- Kemudian disimpan dalam inkubator dengan suhu $37^{\circ} \mathrm{C}$ selama 80 menit atau dalam suhu kamar selama 24 jam. Pada saat tersebut terjadi penguraian ekstrak daging yang melepaskan basa-basa menguap oleh Potassium Karbonat. Basa-basa tersebut kemudian diserap oleh Asam Borat. 
- Pada waktu reaksi itu terjadi, pH larutan akan meningkat dan berubah menjadi basa dan ditandai oleh warna hijau.

- Asam Borat yang mengandung basa-basa menguap segera dititrasi dengan larutan Asam Klorida encer $(0,02 \mathrm{~N}$ HCL)

- Titik akhir titrasi adalah pada waktu Asam Borat kembali warna merah muda atau ke tingkat $\mathrm{pH}$ awal dari larutan. Hal ini berarti titrasi hanya ditujukan untuk pengambilan basa-basa menguap yang terikat pada Asam Borat.

Kadar TVB-N dalam 100 g daging ikan dapat ditentukan dengan rumus berikut:

$$
\begin{aligned}
& \text { TVB-N }\left(\frac{\text { mg } \mathrm{N}}{100 \text { gr daging }}\right)= \\
& (\mathrm{a}-\mathrm{b}) \times 0,28 \times \text { faktor pengenceran } \\
\text { dimana: } & \text { Jumlah ml Asam Klorida }(\mathrm{HCL} 0,02 \mathrm{~N}) \text { yang } \\
\mathrm{a}= & \text { dipakai mentiter larutan sampel. } \\
\mathrm{b}= & \text { Jumlah ml Asam Klorida yang dipakai mentiter } \\
& \text { larutan blanko. } \\
0,28= & \text { Jumlah Ammonium Nitrogen yang setara dengan } \\
& \text { satu ml 0,02 N larutan Asam Klorida. }
\end{aligned}
$$

\section{Total Plate Count}

Total bakteri dianalisa dengan menggunakan metode sebar (Ijong 2003). Metode ini bersifat kuantitatif, dengan menghitung jumlah populasi mikroba yang ada dalam bahan pangan ikan. Mikroba yang tumbuh pada metode ini sebagian besar bersifat aerobic. Prosedur pengujiannya ialah sebagai berikut:

- Semua peralatan yang digunakan dalam analisa mikrobiologis disterilkan terlebih dahulu dengan menggunakan autoclave pada suhu $121^{\circ} \mathrm{C}$, dengan tekanan $15 \mathrm{psi}$, selama 15 menit.

- Disiapkan tabung reaksi yang telah diberi kode, lalu diisi dengan $9 \mathrm{ml} \mathrm{NaCl} 0,9 \%$, kemudian disterilkan.

- Sampel ditimbang $10 \mathrm{~g}$, ditambah $90 \mathrm{ml}$ larutan $\mathrm{NaCl} \quad 0,9 \%$ kemudian diblender sampai homogen. Sampel ini merupakan suspense pengenceran $10^{-1}$

- Selanjutnya diambil $1 \mathrm{ml}$ suspense dari pengenceran di atas dan dipindahkan ke dalam tabung reaksi lain yang telah berisi $0,09 \mathrm{ml} \mathrm{NaCl}$ menjadi suspense pengencer $10^{-1}$. Demikian seterusnya sampai tingkat pengenceran $10^{-5}$.

- Diambil NA yang telah disterilkan dan masih dalam keadaan hangat (suhu kira-kira 37$45^{\circ} \mathrm{C}$ ) secara aseptic sebanyak $15 \mathrm{ml} \mathrm{NA}$ dituangkan ke dalam cawan petri yang telah diberi kode, lalu tunggu sampai media tersebut mengeras.

- Setelah NA mengeras, dari setiap pengenceran diambil masing-masing $1 \mathrm{ml}$ suspensi dan dipindahkan ke dalam media NA yang telah diberi kode, lalu dengan menggunakan batang penyebar gelas steril, suspense tersebut disebarkan di seluruh permukaan media secara merata. Sementara penyebaran suspense dilakukan, cawan petri diputar perlahan-lahan.

- Semua cawan petri dimasukkan ke dalam inkubator dengan posisi terbalik, dan diinkubasi selama 24 jam pada suhu $37^{\circ} \mathrm{C}$.

- Kemudian dihitung jumlah koloni pada masing-masing petri. Untuk mendapatkan hasil yang baik maka setiap pengenceran dibuat duplo. Jumlah koloni yang dihitung pada cawan petri yaitu antara 30-300 koloni dan dalam keadaan koloni bebas.

- Setelah itu, jumlah yang diperoleh dikalikan dengan satu per tingkat pengenceran.

$$
\begin{gathered}
\text { Total Koloni }\left(\frac{\text { cfu }}{\mathrm{g}}\right)= \\
\text { Jumlah Koloni X } \frac{1}{\text { Tingkat Pengenceran }}
\end{gathered}
$$

\section{Uji Organoleptik (SNI 2009)}

Metode uji yang dipakai yaitu uji sensori dengan menggunakan skala angka 1 sebagai nilai terendah dan angka 9 untuk nilai tertinggi. Batas penolakan untuk produk ikan asap ialah 7 artinya bila produk ini diuji memperoleh lebih kecil dari 7 maka produk tersebut dinyatakan tidak memenuhi standar mutu (ditolak). Pengujian organoleptik dengan metode uji sensori.

\section{Analisa Data}

Data yang diperoleh dibedakan menjadi 2 kategori yaitu data kualitatif dan data kuantitatif. Data kualitatif dilakukan cukup dengan menghubungkan makna dari ke lima data uji yang dilakukan. Data kuantitatif adalah data dalam bentuk tabel-tabel, dan grafik. Data untuk uji Kadar air, pH, TVB-N, TPC dan Organoleptik (Rasa, Kenampakan, Bau, dan Tekstur) yang diperoleh, ditentukan ditabulasi dengan mencari nilai rata-rata kemudian disajikan dalam bentuk tabel dan grafik. Selanjutnya hasil tersebut dikaji dan dibandingkan dengan persyaratan mutu ikan cakalang asap. 


\section{HASIL DAN PEMBAHASAN}

\section{Kadar Air}

Berdasarkan hasil penelitian, diperoleh nilai rata-rata kadar air ikan cakalang asap penyimpanan 0 hari pada produk yang dikemas vakum adalah $53,95 \%$ dan pada produk yang tidak dikemas vakum adalah 53,45\%. Pada penyimpanan 7 hari nilai rata-rata kadar air pada produk yang dikemas vakum adalah $54,55 \%$ dan pada produk yang tidak dikemas vakum adalah 49,84\%. Pada penyimpanan 21 hari nilai rata-rata kadar air pada produk yang dikemas vakum adalah $55,79 \%$ dan yang tidak dikemas vakum adalah $20,14 \%$.

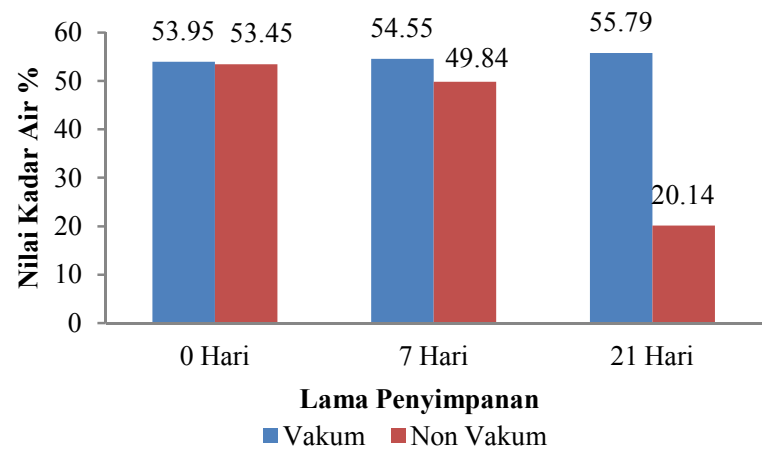

Gambar 1. Nilai Kadar Air ikan Cakalang (Katsuwonus pelamis L.) Asap selama 21 hari penyimpanan pada suhu $\pm 5^{\circ} \mathrm{C}$. $(\mathrm{n}=2)$.

Data hasil penelitian menunjukkan bahwa nilai kadar air sampel ikan cakalang asap pada produk yang dikemas vakum terlihat stabil (tidak mengalami perubahan) nilai kadar airnya selama 21 hari penyimpanan. Hal ini disebabkan karena penyimpanan vakum dapat mempertahankan produk ikan cakalang asap. Nilai kadar air pada produk yang dikemas vakum memilki nilai kadar air yang lebih baik, berdasarkan SNI 2009, mutu ikan asap yang baik memilki kadar air 60\%. Dengan pengemasan vakum juga tidak terjadi penguapan dan penyerapan kadar air bebas. Sedangkan pada produk yang tidak dikemas vakum kadar air terlihat mengalami penurunan yang signifikan selama 21 hari penyimpanan. Hal ini kemungkinan disebabkan akibat penguapan dari produk karena pengaruh suhu dan kelembaban sekitar lebih rendah dari pada kelembaban produk. Winarno (1980), menyatakan bahwa kadar air suatu produk dipengaruhi oleh kelembaban nisbi udara sekelilingnya. Jika kelembaban ruang lebih tinggi, produk akan menyerap air, dan bila kelembaban ruang penyimpanan rendah produk akan menguapkan airnya (Syarief dan Halid, 1980).

Nilai Standar nilai kadar air ikan asap berdasarkan SNI (2009) adalah maksimal 60$65 \%$. Hasil penelitian menunjukkan produk ikan asap yang dikemas vakum dan non vakum selama penyimpanan 21 hari memiliki kadar air masih batas standar yang telah ditentukan oleh SNI (2009). Kadar air merupakan parameter yang penting untuk menentukan kualitas ikan asap yang dihasilkan. Kadar air yang terkandung di dalam ikan asap dapat mempengaruhi daya simpan ikan asap. Karena kadar air merupakan media mikroba untuk berkembang biak (Agus, dkk. 2014). Penyimpanan pada suhu dingin dengan menggunakan lemari es yang pemakaiannya tidak maksimal dapat mempengaruhi naik turunnya kadar air pada produk yang dikemas vakum.

\section{Penentuan Derajat Keasaman (pH)}

Berdasarkan hasil penelitian, diperoleh nilai rata-rata $\mathrm{pH}$ ikan cakalangasap penyimpanan 0 hari pada produk yang dikemas vakum dan yang tidak dikemas vakum yaitu masing-masing 5,8. Nilai rata-rata $\mathrm{pH}$ ikan cakalang asap pada 7 hari penyimpanan pada produk yang dikemas vakum yaitu 5,8 dan yang tidak dikemas vakum yaitu 5,9. Nilai rata-rata $\mathrm{pH}$ pada 21 hari penyimpanan pada produk yang dikemas vakum yaitu 5,8 sedangkan pada produk yang tidak dikemas vakum yaitu 5,9.

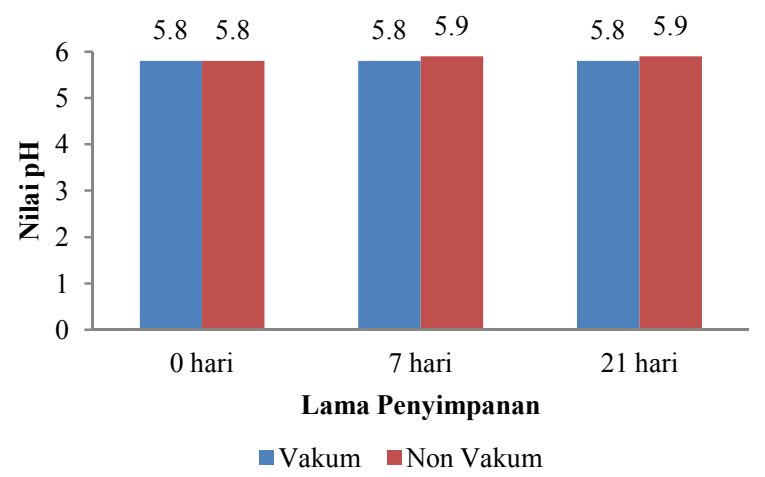

Gambar 2. Nilai pH ikan Cakalang (Katsuwonus pelamis L.) Asap selama 21 hari penyimpanan pada suhu $\pm 5^{\circ} \mathrm{C}$. $(\mathrm{n}=2)$.

Dari data hasil penelitian menunjukkan bahwa nilai $\mathrm{pH}$ pada produk yang dikemas vakum nilai $\mathrm{pH}$-nya tidak berubah dan tetap stabil sampai hari ke-21 dibandingkan produk yang tidak dikemas vakum nilai $\mathrm{pH}$-nya lebih 
cepat mengalami kenaikan pada penyimpanan 7 hari. Dapat dilihat selama penyimpanan produk yang dikemas vakum dan tidak dikemas vakum tidak selalu mengalami peningkatan nilai $\mathrm{pH}$. Hal ini menunjukkan semakin rendah suhu yang digunakan maka aktifitas enzim semakin terhambat. Menurut Hadiwiyato (1993) daging ikan yang mempunyai $\mathrm{pH}$ tinggi disebabkan karena timbulnya senyawa-senyawa yang bersifat basa seperti amoniak, trimetilamin, dan senyawa-senyawa volatile lainnya, yang juga dapat menurunkan nilai organoleptik dari produkt. Proses glikolisis, enzim sangat berperan sampai terbentuknya asam laktat. Hal ini menyebabkan akumulasi asam laktat berjalan lebih lambat sehingga penurunan $\mathrm{pH}$ ikan juga berlangsung lebih lambat (Munandar, 2009).

Chamidah (2000) menyatakan bahwa selama penyimpanan terjadi penguraian protein menjadi senyawa basa antara lain amoniak. Nilai $\mathrm{pH}$ bahan pangan selama penyimpanan dapat berubah karena adanya protein yang terurai oleh enzim proteolitik dan bantuan bakteri menjadi asam karboksilat, asam sulfida, amoniak dan jenis asam lainnya. Oleh karena itu nilai $\mathrm{pH}$ ikan cakalang asap yang dihasilkan walaupun meningkat tetapi masih pada kondisi asam. Nilai $\mathrm{pH}$ merupakan salah satu indikator yang digunakan untuk menetukan tingkat kesegaran ikan. Pada proses pembusukan ikan, perubahan $\mathrm{pH}$ daging sangat besar perananannya karena berpengaruh terhadap proses autolysis dan penyerangan bakteri.

Menurut Fardiaz (1982) $\mathrm{pH}$ yang baik untuk ikan yang diawetkan $\mathrm{pH}$ antara $6,0-8,0$ merupakan media yang baik untuk pertumbuhan mikroorganisme. Nilai $\mathrm{pH}$ yang didapat pada penelitian ini pada produk yang dikemas vakum dan tidak dikemas vakum masih termasuk dalam kriteria mutu yang baik sampai penyimpanan 21 hari.

\section{Analisis TVB-N}

Berdasarkan hasil penelitian, diperoleh nilai rata-rata TVB-N ikan cakalang asap penyimpanan 0 hari pada produk yang dikemas vakum adalah $21,84 \mathrm{mg} \mathrm{N} / 100$ gr sampel dan yang tidak dikemas vakum adalah $23,52 \mathrm{mg}$ N/100 gr sampel. Nilai rata-rata TVB-N penyimpanan 7 hari pada produk yang dikemas vakum yaitu $29,4 \mathrm{mg} \mathrm{N} / 100 \mathrm{gr}$ sedangkan non vakum adalah 43,26 mg N/100 gr sampel. Nilai rata-rata TVB-N penyimpanan 21 hari pada produk yang dikemas vakum adalah $27,72 \mathrm{mg}$ $\mathrm{N} / 100$ gr sedangkan non vakum adalah $45,36 \mathrm{mg}$ $\mathrm{N} / 100$ gr sampel.

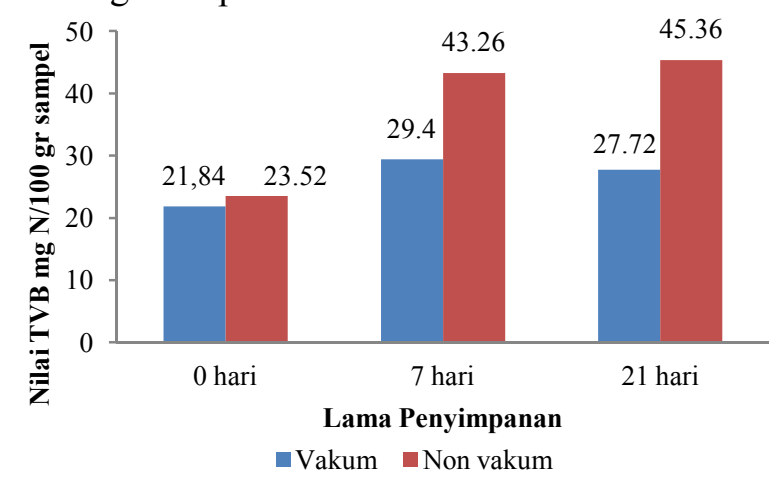

Gambar 3. Nilai TVB-N ikan Cakalang (Katsuwonus pelamis L.) Asap selama 21 hari penyimpanan pada suhu $\pm 5^{\circ} \mathrm{C}$. $(n=2)$.

Data hasil penelitian menunjukkan bahwa nilai TVB-N pada produk yang dikemas vakum dan tidak dikemas vakum selama penyimpanan mengalami kenaikan nilai TVB-N nya. Dari Gambar dapat dilihat kandungan nilai TVB pada produk yang tidak dikemas vakum lebih tinggi kenaikan nilai TVB-nya dibandingkan pada produk yang dikemas vakum. Peningkatan ini terjadi kemungkinan karena aktivitas enzim pengurai mulai bekerja. Peningkatan nilai TVB-N seiring bertambahnya julah bakteri, karena salah satu hasil penguraiandari bakteri adalah senyawa yang tergolong basa-basa menguap. Peningkatan nilai TVB-N dapat dipengaruhi oleh jenis makanan yang dimakan dan kandungan bakteri ikan tersebut (Berhimpon 1993). Menurut Suwetja (1993), kerja bakteri dalam merombak protein dan asam-asam amino menjadi senyawasenyawa yang lebih sederhana untuk dapat tumbuh dan berkembang biak menghasilkan senyawa-senyawa sisa seperti NH3, trimetilamin dari senyawa-senyawa turunannya dimana senyawa-senyawa ini termasuk golongan basa-basa menguap. TVB-N digunakan sebagai batasan yang layak dikonsumsi.

Dari penelitian ini nilai rata-rata Total Volatile Base dari produk yang dikemas vakum dan tidak vakum yang disimpan selama 21 hari penyimpanan masih memenuhi kriteria yang baik. Batas pembusukan dari produk ikan olahan (ikan yang dikeringkan dan digarami) menurut SNI adalah 100m - $120 \mathrm{mg} \mathrm{N} / 100$ gram. Yunizal dkk., (1994), menyatakan keadaan dan jumlah kadar TVB-N tergantung 
pada mutu kesegaran ikan, makin mundur mutu ikan, kadar TVB-N akan meningkat jumlahnya.

\section{TPC}

Berdasarkan hasil penelitian nilai Total Plate Count diperoleh nilai rata-rata TPC ikan cakalang asap selama penyimpanan pada produk yang dikemas vakum dan non vakum.

Tabel. 1. Data Hasil Total Plate Count (TPC).

\begin{tabular}{|c|c|c|c|c|c|}
\hline 胥 & 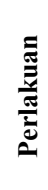 & 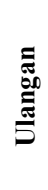 & 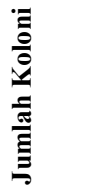 & 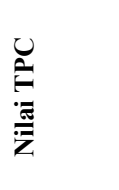 & $\stackrel{\Delta}{\Delta}$ \\
\hline \multirow{2}{*}{ A1 } & B1 & $\begin{array}{l}1 \\
2\end{array}$ & $\frac{15 \times 10^{1}}{28 \times 10^{1}}$ & $2,15 \times 10^{2}$ & $<30$ \\
\hline & B2 & $\begin{array}{l}1 \\
2\end{array}$ & $\frac{46 \times 10^{1}}{84 \times 10^{2}}$ & $4,43 \times 10^{3}$ & \\
\hline \multirow[b]{2}{*}{ A2 } & B1 & $\begin{array}{l}1 \\
2\end{array}$ & $\frac{11 \times 10^{1}}{0 \times 10^{1}}$ & $5,5 \times 10^{1}$ & $<30$ \\
\hline & B2 & $\frac{1}{2}$ & $\begin{array}{r}3 \times 10^{1} \\
78 \times 10^{2}\end{array}$ & $40,5 \times 10^{3}$ & \\
\hline \multirow{2}{*}{ A3 } & B1 & $\begin{array}{l}1 \\
2\end{array}$ & $\begin{array}{r}13 \times 10^{3} \\
9 \times 10^{1}\end{array}$ & $22 \times 10^{4}$ & $<30$ \\
\hline & B2 & $\begin{array}{l}1 \\
2\end{array}$ & $\begin{array}{l}\text { TBUD } \\
\text { TBUD }\end{array}$ & TBUD & \\
\hline
\end{tabular}

Dari data menunjukkan pada produk yang dikemas vakum masih terlihat lebih sedikit koloni bakteri yang tumbuh dibandingkan produk yang tidak dikemas vakum. Hasil penelitian menunjukkan selama penyimpanan terjadi peningkatan nilai TPC pada produk yang tidak dikemas vakum. Peningkatan ini kemungkinan bisa disebabkan pada saat pengambilan sampel ke-0hari penanganan ikan dari tempat pengolah kurang memperhatikan sanitasi dan hygiene selama pengolahan hingga produk akhir, sehingga dapat mengontrol terjadinya kontaminasi dan perkembangbiakan mikroba. Menurut Moeljanto (1992) baik dan buruknya penanganan sangat menentukkan mutu ikan sebagai bahan mentah untuk pengolahan lebih lanjut. Mutu dari suatu produk akhir akan ditentukan oleh keadaan sanitasi dan hygiene dari bahan mentah, selama pengolahan hingga menjadi produk akhir. (IIyas, 1972).

Hasil penelitian menunjukkan pada produk yang dikemas vakum menunjukkan jumlah bakteri lebih rendah, hal ini kemungkinan disebabkan karena tidak tersedianya oksigen untuk kebutuhan metabolisme dari bakteri, sehingga bakteri sulit untuk berkembang biak walaupun kadar air yang dikandung produk cukup untuk aktifitas bakteri. Ketersedian oksigen juga membatasi pertumbuhan mikroba akan terhambat. llyas (1983), pertumbuhan bakteri pada ikan sangat dipengaruhi oleh suhu, semakin rendahnya suhu ikan semakin lambat pertumbuhan bakteri. Selanjutnya Anonimous (1988) menyatakan bahwa selama penyimpanan akan terjadi perubahan dekomposisi baik oleh flora bakteri maupun oleh enzim proteolitik. Pada penyimpanan 7 hari dan 21 hari sudah terjadi peningkatan nilai koloni bakteri pada produk yang tidak dikemas vakum, hal ini disebabkan bakteri dan kapang mulai bertumbuh dan berkembang biak. Hal ini dipertegas oleh Buckle dkk. (1985), bahwa pada tahap awal pertumbuhan mikroorganisme belum terjadi pembelahan sel. Selanjutnya setelah mampu beradaptasi dengan lingkungannya yang baru, sel-sel bakteri akan tumbuh dan membelah secara eksponsil sampai jumlah yang maksimum.

Dari hasil penelitian ini, produk yang dikemas vakum masih memenuhi syarat mutu ikan asap yang direkomendasikan oleh Badan Standar Nasional Indonesia (SNI 2009) sampai penyimpanan ke-21 hari, sedangkan produk yang tidak dikemas hanya sampai 7 hari. Dimana batas maksimum nilai TPC adalah $1,0 \mathrm{x}$ 105 koloni/ gram.

\section{Pengujian Organoleptik Rasa}

Berdasarkan hasil penelitian, diperoleh nilai rata-rata organolepik (rasa) ikan cakalang asap selama penyimpanan pada produk yang dikemas vakum $6,9-8,2$, sedangkan nilai ratarata organoleptik (rasa) pada produk non vakum $6,3-7,7$.

Berdasarkan Gambar 4 dapat dilihat bahwa nilai rata-rata organoleptik (rasa) selama penyimpanan pada produk yang dikemas vakum dan non vakum mengalami penurunan nilai organoleptiknya dari segi rasa. Menurunnya cita rasa yang khas pada produk ikan asap selama penyimpanan kemungkinan bisa disebabkan oleh senyawa-senyawa asap seperti fenol yang mengendap pada daging ikan mengalami penguapan Winarno, dkk (1983) menyatakan bahwa garam dapur akan menghasilkan berbagai pengaruh terhadap bahan pangan terutama dapat menghambat pertumbuhan mikroba pembusuk yang mengkontaminasi. Rasa yang tidak enak disebabkan oleh faktor 
lingkungan yang mendukung pertumbuhan mikroba selama penyimpanan misalnya kadar air, suhu, 02, sehingga tumbuhnya mikroba akan merusak daging, dan tingkat konsumen menurun. Berdasarkan penilaian panelis nilai citarasa terbaik adalah pada produk yang dikemas vakum. Produk yang dikemas vakum dengan lama penyimpanan 7 hari, nilai organoleptik dari segi rasa masih disukai panelis. Nilai persyaratan mutu ikan asap yang direkomendasikan menurut SNI yaitu minimal 7.

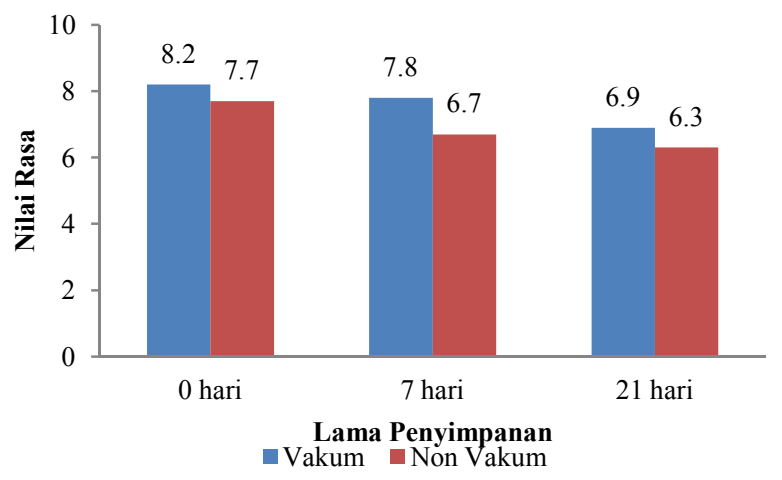

Gambar 4. Hasil penilaian panelis terhadap nilaiorganoleptik (Rasa) Ikan Cakalang (Katsuwonus pelamis L.) Asap selama penyimpanan 21 hari pada suhu $\pm 5^{\circ} \mathrm{C}$. $(\mathrm{n}=\mathbf{2})$.

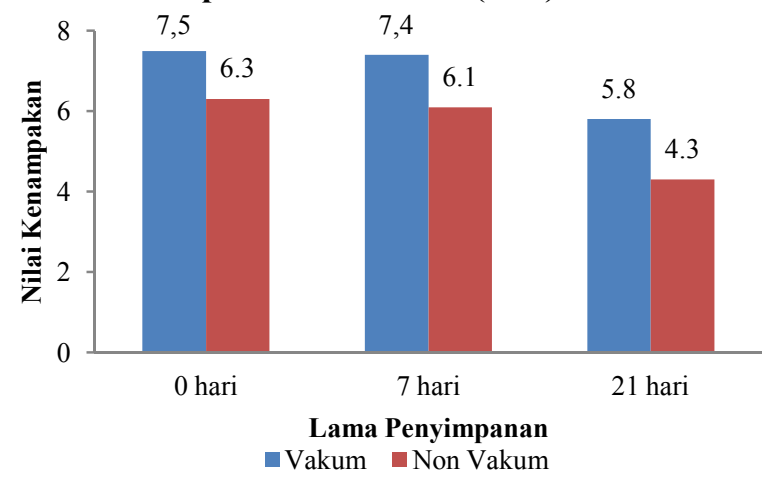

Gambar 5. Hasil penilaian panelis terhadap nilai organoleptik (Kenampakan) Ikan Cakalang (Katsuwonus pelamis L.) Asap selama penyimpanan 21 hari pada suhu $\pm 5^{\circ} \mathrm{C}$. $(\mathrm{n}=2)$.

\section{Kenampakan}

Berdasarkan hasil penelitian, diperoleh nilai rata-rata organolepik (kenampakan) ikan cakalang asap selama penyimpanan pada produk yang dikemas vakum $5,8-7,5$ dan pada produk yang tidak dikemas vakum 4,3-6,3.

Berdasarkan gambar 6 menunjukkan bahwa semakin lama waktu penyimpanan menyebabkan nilai organoleptik dari segi kenampakan semakin menurun pada produk yang dikemas vakum dan non vakum. Hal ini kemungkinan disebabkan oleh semakin tingginya kandungan air dalam tubuh ikan yang memungkinkan menguapnya senyawa-senyawa asap selama disimpan serta diakibatkan hampir seluruh bagian tubuh ikan sudah ditumbuhi oleh jamur sehingga kelihatan sudah tidak layak lagi. Menurut Moeljanto (1992) menyatakan bahwa warna ideal dari ikan hasil proses pengasapan adalah warna kuning emas kecoklatan. Berdasarkan penilaian panelis nilai kenampakan terbaik adalah produk yang dikemas vakum dengan lama penyimpanan 7 hari, nilai organoleptik dari segi kenampakan masih disukai panelis, masih baik, masih terlihat menarik, bersih namun sudah agak kusam. Nilai persyaratan mutu ikan asap yang direkomendasikan menurut SNI yaitu minimal 7.

\section{Bau}

Berdasarkan hasil penelitian, diperoleh nilai rata-rata organoleptik (bau) ikan cakalang asap selama penyimpanan pada produk yang dikemas vakum 5,8-8,9 dan pada produk yang tidak dikemas vakum $4,3-7,5$.

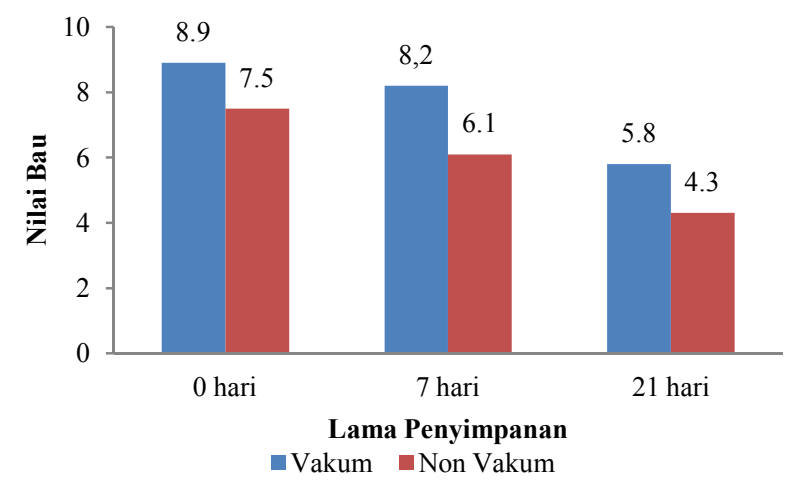

Gambar 6. Hasil penilaian panelis terhadap nilai organoleptik (Bau) Ikan Cakalang (Katsuwonus pelamis L.) Asap selama penyimpanan 21 hari. $(\mathbf{n}=2)$

Berdasarkan gambar 6 menunjukkan bahwa lama penyimpanan sangat mempengaruhi nilai organoleptik dari segi bau ikan cakalang asap. Dari gambar dapat dilihat bahwa produk yang dikemas vakum dan non vakum selama penyimpanan mengalami penurunan. Penurunan ini kemungkinan diakibatkan oleh timbulnya jamur pada ikan sehingga menyebabkan ikan mulai berbau tengik. Rata-rata panelis menilai ada sedikit bau tambahan pada produk ikan asap dan panelis menilai kurang harum. Kurangnya nilai bau 
tersebut diduga sebagai akibat pelepasan senyawa-senyawa lain yang tidak dikehendaki yang ikut bersama-sama di dalam asap.

$$
\text { Widiastuti (2007) menyatakan }
$$

kehadiran mikroorganisme pada ikan juga mengakibatkan perubahan bau. Bau tersebut timbul akibat timbulnya amoniak (NH3) pada degradasi protein dan gas $\mathrm{H} 2 \mathrm{~S}$ pada degradasi protein yang mengandung unsur sulfur oleh bakteri pembentuk gas H2S. Nilai bau menunjukkan bahwa ikan cakalang asap dengan perlakuan pengemas memperoleh nilai tertinggi sedangkan ikan cakalang asap dengan perlakuan tanpa pengemas terendah. Berdasarkan penilaian panelis nilai bau terbaik adalah produk yang dikemas vakum dengan lama penyimpanan 7 hari, nilai organoleptik dari segi bau masih disukai panelis, bau asap masih tercium dan produk masih baik. Nilai persyaratan mutu ikan asap yang direkomendasikan menurut SNI yaitu minimal 7.

\section{Tekstur}

Berdasarkan hasil penelitian, diperoleh nilai rata-rata organoleptik tekstur ikan cakalang asap selama penyimpanan pada produk yang dikemas vakum 5,1-7,9 dan pada produk yang tidak dikemas vakum 4,9-7,7.

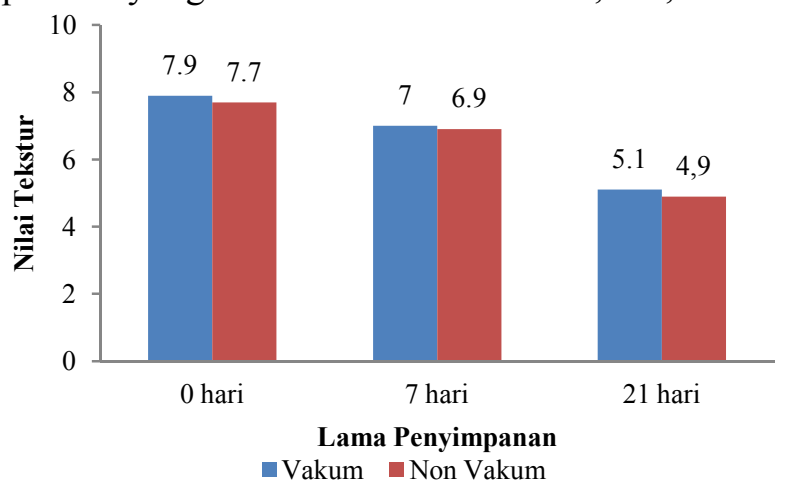

Gambar 7. Hasil penilaian panelis terhadap nilai organoleptik (Tekstur) Ikan Cakalang(Katsuwonus pelamis L.) Asap selama penyimpanan 21 hari pada suhu $\pm 5^{\circ} \mathrm{C}$. $(\mathrm{n}=2)$.

Berdasarkan gambar 7 menunjukkan bahwa produk yang dikemas vakum dan non vakum selama penyimpanan mengalami penurunan nilai organoleptiknya dari segi tekstur. Nilai tekstur suatu produk dipengaruhi juga oleh kadar air daging ikan yang segar dan perendaman dalam air garam dapat mengurangi kadar air, menghambat pertumbuhan mikroba, sehingga menyebabkan daging ikan lebih kompak, tekstur lebih baik dan disukai panelis, untuk produk ikan asap kemas vakum yang disimpan dingin teksturnya lembab disebabkan karena kadar air yang meningkat selama penyimpanan.

Selain pengaruh kadar air, menurut Bustan, dkk (1982) dalam Tribowo (1985) aksi bacterial maupun enzim mengakibatkan degradasi jaringan pengikat yang menyebabkan penurunan nilai tekstur sehingga menjadi lunak. Mikroba yang ada menghasilkan benang-benang jamur dan lendir-lendir yang membuat nilai bau, tekstur dan penampakan semakin rendah. Berdasarkan penilaian panelis nilai tekstur masih dalam kriteria yang baik adalah produk yang dikemas vakum dengan lama penyimpanan sampai 7 hari dan produk yang tidak dikemas vakum hanya sampai penyimpanan 0 hari masih disukai panelis. Nilai persyaratan mutu ikan asap yang direkomendasikan menurut SNI yaitu minimal 7.

\section{KESIMPULAN}

Berdasarkan hasil penelitian yang dilakukan, maka dapat ditarik kesimpulan sebagai berikut :

- Berdasarkan hasil uji kimiawi nilai pH dan kadar air, dan nilai TVB ikan Cakalang asap yang disimpan dengan produk yang dikemas vakum memilki mutu yang lebih baik dibandingkan dengan produk yang dikemas non vakum selama 21 hari penyimpanan dingin.

- Berdasarkan hasil uji mikrobiologi nilai TPC, ikan Cakalang asap yang dikemas vakum termasuk dalam criteria mutu yang baik sampai 21 hari penyimpanan, sedangkan produk yang tidak dikemas vakum hanya sampai di 7 hari penyimpanan karena di 21 hari penyimpanan jumlah koloni bakteri pada produk sudah melebihi Standar Nasional Indonesia $(1,0 \times 105)$.

- Berdasarkan hasil uji organoleptik dari segi kenampakan, rasa, dan bau,dan tekstur ikan cakalang asap yang dikemas vakum memilki nilai sensori lebih baik dibandingkan pada produk yang dikemas non vakum.

\section{DAFTAR PUSTAKA}

Adwyah, R. 2008. Pengolahan dan Pengawetan Ikan. Penerbit. Bumi Aksara. Jakarta.

Agus. T.S.W., F. Swastawati, da A.P. Anggo. 2014. Kualitas Ikan PAri (Dasyatis sp) Asap Yang Diolah 
Dengan Ketinggian Tungku Dan Suhu Yang Berbeda. Jurnal Pengolahan dan Bioteknologi Hasil Perikanan, vol 3. No.1 hal 147-156. http://www.ejournalsl,undip.ac.id/index.php/jpbhp. Diakses: 27 April 2014.

Anonimous, 1988. "Prosiding Pertemuan Teknis Peranan Metode Pendiginan Dalam Mendukung Pemasaran Ikan Segar. Sub Balai Penelitian dan Pengembangan Pertanian. Departemen Pertanian. Jakarta.

Anonimous, 1993.“Jurnal Penelitian Laut”. Balai Penelitian dan Pengembangan Pertanian. Jakarta.

Anonimous, 2010. Studi Pengembangan Dan Penerapan Teknik Pengasapn Ikan Tongkol Di Kabupaten Natuna. Laporan Akhir BPP-PSPL UNRI.

Berhimpon,S., H. Dien, R. Montolalu, 2002. Processing and The Prospect of Katsuobushi (Ikan kayu) of NorthSulawesi, Indonesia : A Review. Fish Handling and Processing Laboratory. Faculty of Fisheries and MarineScience. Sam Ratulangi University. Manado

Buckle, K. A. Edwards, R.A., Fleet, G.H., Wootlon, M 1987. Ilmu Pangan. Diterjemahkan oleh Hari Purnomo dan Adiono. UI-Press. Jakarta.

Fardiaz, S., 1982. "Mikrobiologi Pangan". Jilid 1. Jurusan Ilmu dan Teknologi Perikanan. Jakarta.

Hadiwiyoto, S. 1993. Teknologi Pengolahan Hasil Perikanan. Jilid I. Penerbit Liberty. Yogyakarta.

IIyas, S, 1983. "Teknologi Refrigrasi Hasil Perikanan". Jilid 1. Teknik Pendinginan Ikan. C. V. Paripurna, Jakarta.

Isamu Kobajashi T. Hari Purnomo Dan Sudarminto S. Yuwono. 2012. Karakteristik Fisik, Kimia, Dan Organoleptik Ikan Cakalang (Katsuwonus Pelamis) Asap Di Kendari. Jurnal Teknologi Pertanian Vol. 13 No. 2 [Agustus 2012] 105-110

Isamu, K.T., H. Purnomo., dan S.S. Yuwono. 2012. Karakteristik Fisik, Kimia, Dan Organoleptik Ikan Cakalang (Katsuwonus pelamis) Asap Di Kendari. Jurnal Teknologi Pertanian Vol.13 No.2 Agustus 2012 105-110.

Jay. 1996. Modern Food Microbiology 4th edition. New York: D Von Nostrand Company.

Juniarto. 2003. Teknik Penanganan Ikan. Penebar Swadaya. Jakarta

Kose, S. 2003. An Investigation of Quality In Anchovy (Engraulis ancarasicolus). Stored at Different Temperaturs. Turk J Vet Anim Sci 28 ; 575-582.

Munandar. Aris. Et, al. 2009. Kemunduran Mutu Ikan Nila (Oreochromis niloticus) Pada Penyimpanan Suhu Rendah dengan Perlakuan Cara Kematian dan Penyiangan. Institut Pertanian Bogor.

Moeljanto, R. 1992. "Pengawetan dan Pengolahan Hasil Perikanan”. Penerbit Swadaya. Jakarta.

Pandit, Suranaya. 2010. Research of Cloride Test in Sulphate Acid Commodity. Fakultas Teknik Jurusan Kimia Universitas WR. Supratman. Surabaya.

Puspabuana Ovilia, 2013. Pengolahan Pengasapan Ikan. Universitas Brawijaya Malang. http://adecovilia.blogspot.com/2013/10/makalahpengolahan-pengasapan-ikan.html. Tanggal Akses: 22 Oktober 2013.
Rahayu, S., Nudinah, Nasran S., 1982. Pengaruh Penggaraman Pendahuluan Bahan Mentah Terhadap Mutu Produk Pindang, dalam ; Laporan Penelitian Teknologi Perikanan No.17 Tahun 1982. B.L.T.P. Jakarta.

Robertson GL. 2010. Food Packaging and Shelf Life: A Pratical Guide. CRC Press. Florida.

Rustamadji. 2009. Persentase Kadar Air dan TMA. BFirst . Jakarta.

Swastawati, Fronthea. 2011. Studi Kelayakan Dan Efisiensi Usaha Pengasapan Ikan Dengan Asap Cair Limbah Pertanian. Fakultas Perikanan Dan Ilmu Kelautan Universitas Diponegoro. Semarang

Saanin, 1968. Taksonomi dan Indentifikasi Ikan 2. Pt. bina Cipta. Bogor. Jawa Barat

S. Rahmadana 2013 , Analisa Masa Simpan Rendang Ikan Tuna dalam Kemasan Vakum Selama Penyimpanan Pada Suhu Dingin. Universitas Hassanudin Makassar. http://repository.unhas.ac.id/bitstream/handle/123456 789/6001/Skripsi\%20Lengkap\%20Rahma.pdf?sequen $\mathrm{ce}=1$

(SNI) Standard Nasional Indonesia. 2009. Ikan Asap Bagian 1. Spesifikasi. SNI 27 25.1:2009. Badan Standardisasi Nasional. Jakarta.

(SNI) Standard Nasional Indonesia. 2009. Ikan AsapBagian 3. Pananganan Dan Pengolahan. SNI 2725.3:2009. Badan Standardisasi Nasional. Jakarta.

(SNI) Standard Nasional Indonesia. 2011. Petunjuk Pengujian Organoleptik Dan Atau Sensori Pada Produk Perikanan. SNI 2346:2011. Badan Standardisasi Nasional. Jakarta.

Sunarsih, S., Y. Pratiwi., dan Y. Sunarto. 2012. Pengaruh Suhu, Waktu Dan Kadar Air Pada Pembuatan Asap Cair Dari Limbah Padat Pati Aren. Prosiding Seminar Nasional Aplikasi Sains dan Teknologi (SNAST) Periode III. Yogyakarta 3 November 2012. ISSN: 1979-911X.

Suwetja, I.K., 1993. "Metode Penentuan Mutu Ikan". Jilid 1. Penentuan Kesegaran. Fakultas Perikanan Dan Ilmu Kelautan. Unsrat. Manado.

Suwetja, I.K. 2011. Biokimia Hasil Perikanan, buku. Diterbitkan Oleh Media Prima Aksara. Jakarta. 204h

Syarif, R., H. Halid. 1993. "Teknologi Penyimpanan Pangan Arcan". Bogor

Tilahunga, H. 2003. "Kajian Mutu Ikan Cakalang (Katsuwonus Pelamis L) Asap hasil Modifikasi Proses Pengasapan Pada Usaha Pengasapan Ikan di Girian Weu Kota Bitung". Skripsi. Fakultas Perikanan dan Ilmu Kelautan. Unsrat. Manado.

Tim Peneliti BPP-PSPL UNRI. 2010. Studi Pengembangan Dan Penerapan Teknik Pengasapan Ikan Tongkol Di Kabupaten Natuna. Laporan Akhir. BPP-PSPL UNRI.

Tranggono dan Sutardi. 1990. Biokimia dan Teknologi Pasca Panen. Universitas gadjah mada:Yogyakarta

Tri Margono, Detty Suryati, Sri Hartinah. 1993. Buku Panduan Teknologi Pangan. Pusat Informasi Wanita dalam Pembangunan PDII-LIPI bekerjasama dengan Swiss Development Cooperation.

Widiastuti, I.M.2007. Sanitasi dan Mutu Kesegaran Ikan Konsumsi pada Pasar Tradisional Di Kotamadya Palu. Jurnal. Agroland 14 (1):77-81 ISSN: 0854-641X. 
Winarno, 1993. "Pangan dan Gizi". Teknologi dan Konsumen”. PT. Gramedia Pustaka Utama. Jakarta.
Winarno, F.G. 1997. Kimia Pangan dan Gizi. Gramedia; Jakarta. 